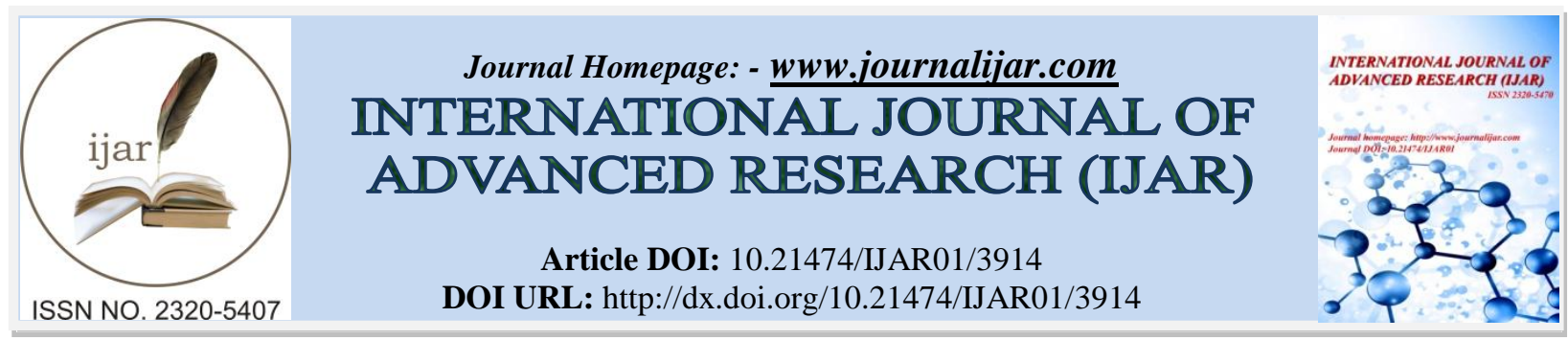

RESEARCH ARTICLE

\title{
DETERMINANTS OF SUSTAINABILITY OF BACKYARD PIG FARMING IN THE PHILIPPINES.
}

Editha R. Perey, Ph. D.

Professor, College of Agriculture, Laguna State Polytechnic University (Siniloan Campus), Siniloan, Laguna, Philippines.

\section{Manuscript Info}

Manuscript History

Received: 14 February 2017

Final Accepted: 20 March 2017

Published: April 2017

Key words:-

backyard pig farming, decision,

determinants, logit regression,

sustainability

\section{Abstract}

The purpose of this study was to investigate the factors that determine the sustainability of backyard pig raising in the Philippines. This was based on the situation that the decision of Filipino farmers on whether to engage continuously or not in backyard pig farming is dependent on some characteristics of the farmer himself, his household and the farm's immediate environment. The population consisted of all the backyard pig farmers in the municipality of Siniloan, province of Laguna. Empirical data were collected from 60 farmers with the use of questionnaires and interview. Among the farmer-respondents, less than majority $(43.33 \%)$ were able to sustain production. The results of a logit regression model showed that family income, farmers' organizational affiliation, whether the farmer is a contract or an independent producer, access to credit other than banks, and exposure to extension services have significant influence on the decision of farmers on whether to continue or stop in backyard pig farming. On the other hand, age, educational attainment, number of dependents, household size, gender, access to bank credit, access to market, and complaints by neighbors were not significant factors that determine the farmers' decision to engage continuously in pig farming. Thus, the significantly influential factors can be considered in taking initiatives to make backyard pig farming sustainable and contribute to the economic lives of the Filipinos especially in the rural areas in the Philippines.

Copy Right, IJAR, 2017,. All rights reserved.

\section{Introduction:-}

Swine production is an important industry and it is one of the most popular business enterprises in the Philippines. Its popularity can be attributed to its profitability, and to good market for finished hogs and pork. It can be engaged in micro or small to large scale. The average rural Filipino household usually raises a small number of pigs to augment their needs for cash and/or food and for planned and emergency expenses. Aside from being a source of income, there are other reasons why households keep pigs. Pig raising provides job opportunities, economic role for certain members of the household particularly women, children and the aged, and utilization of kitchen leftovers, vegetable trimmings and by-products of farm products processing.

In the Philippines, backyard pig farming operations are found all over the country, while commercial pig farming operations are centered around the major urban area market of Metro Manila. There is proliferation of backyard pig producers which dominate the country's swine industry. About $68.15 \%$ of the total fattener stocks were raised in 
backyard farms and the rest were in commercial farms. However, in 2015 to 2016, a decrease was observed in the number of fatteners raised in the backyard. As of July 1, 2016, the total inventory of fatteners raised in backyard farms was at 2.49 million heads. This was 3.23\% lower than 2015's level of 2.57 million heads (Philippine Statistics Authority, 2016). The participation of backyard farms is important in the Philippine pig industry, hence, backyard pig farming should be sustainable.

The concept of sustainability usually refers to the long term, and sustainable swine production was described by Querol (2011) as involving minimization of the environmental degradation, local water resources pollution and GHG emission while generating income for farmers. In this study, sustainability of backyard pig production is described as the continuous raising of fattening pigs for at least six production cycles within 3 years. The logic in this description is that a farmer cannot continue with his/her backyard pig farming if he/she is constrained by unfavorable factors within oneself, his/her household, and the immediate environment. Swine farming is more capital intensive than raising other livestock. Grown in confinement, pigs depend on care and management by the owner. It takes 3-5 months before growing-finishing pigs reach market weight. Income is collected only after this period but the farmer has to spend everyday, largely on feed, to support growth. Feed cost is $70-80 \%$ of the total cost of producing growing-finishing pigs. Without other source of income it is difficult for a low-income farmer to sustain pig production.

Philippine Statistics Authority (2016) defined backyard farm as any farm or household whether farming or nonfarming raising 1-20 heads of adult animals. As adopted from this definition, backyard pig farming, in this study, refers to raising of 1-20 heads of growing-finishing pigs. Stanton et al. (2010) identified two broad subsectors in the Philippine pig farming industry and these are the backyard subsector and the commercial subsector. Backyard subsector comprises two types of farmers- the subsistence producers and the small-holder pig producers.

Backyard pig farmers in this study are similar to what was termed by Stanton et al. (2010) as "small-holder pig producers" who are either independent producers or contract farmers. They are also characterized as operating as family enterprise tending up to 20 heads of mainly hybrid pigs or crosses of exotic standard breeds that are procured from nearby commercial pig farms or government breeding stations; having source of income other than pig farming; investing in facilities and capital equipment, for example, pig housing and pens and production equipment; and generally feeding pigs with commercially formulated feed with nutrient supplements that are sourced from local agricultural and veterinary products distributors.

Backyard pig production systems in the municipality of Siniloan (the study area) are characterized by confining the animals in pens usually with concrete floor, feeding with commercially formulated feed, and usually without the services of veterinarian. Nevertheless, they have access to services of extensionists of the Municipal Agriculture Office of the Department of Agriculture (DA) and the Laguna State Polytechnic University (LSPU) which College of Agriculture is located in Siniloan Campus. Preliminary survey in the municipality revealed that many backyard pig farmers stop engaging in production after one or two production cycles but there are also those who re-enter into the venture when their situation becomes favorable to pig raising. The backyard pig farming business then is typified by alternating exit-entry/re-entry of farmers into the system. It was compared by the president of ProPork, a large pork federation in the Philippines, to tide of islands-sometimes they are seen, sometimes they disappear (PigProgress, 2016). This means farmers might enter into pig farming, stop for a while and at other times get back to the venture.

There are factors at the farmer's and/or household level and environmental limitations that influence the decision and capacity of the farmer to engage continuously in backyard pig production. As this sector produces more than $68 \%$ of the fatteners in the country, it is important that the factors affecting its sustainability be studied. This study investigated the factors that influenced the sustainability of backyard pig farming in the municipality of Siniloan. Numerous literatures on determinants of adoption of agriculture technologies are available but only few on factors that determine sustainability of small business ventures in the field of animal production. Since continuously engaging in a productive activity like pig production is analogous to adopting a technology- both involves decision making which may be affected by many factors in the situation of the farmer, most of the literatures used in the discussion were on determinants of technology adoption. 


\section{Methodology:-}

Descriptive research method with survey, ocular observation, and use of secondary sources was used. The respondents were 60 backyard pig farmers; 26 of them had sustainable and 34 had non-sustainable backyard pig farming. They were interviewed with the use of structured questionnaire. The municipality of Siniloan in the province of Laguna was the study area. Laguna ranks fourth in backyard pig production in Region IV-A (CALABARZON), which in turn, ranks second in hog production in the Philippines (Philippine Statistics Authority, 2016). Siniloan was chosen as the project site since the characteristics of backyard pig farming in this municipality are believed to be an approximation of all periurban backyard pig production systems in the country.

A list of hog raisers (at least those who registered) as of December 2015, was requested from the Municipal Agricultural Office of Siniloan. For this study the definition of Philippine Statistics Authority (2016) that backyard pig farming is the raising of 1-20 adult pigs was adopted.

\section{Statistical analysis:-}

Statistical tools and techniques such as mean and standard deviation were used in comparing the group of farmers with sustainable backyard pig farming and the group whose pig farming was not sustainable. Two-sample t-statistic was used to test for significant differences between the two groups' characteristics. Binary logistic regression analysis was used to identify the significant factors that, in combination, determine the sustainability of backyard pig farming. Binary logistic regression examines the relationship between one or more predictor variables and a binary response (Minitab Inc., 2013). The binary response variable in this study is whether backyard pig farming is sustainable or not sustainable.

\section{Measurement of dependent and explanatory variables:-}

The dependent variable was dichotomized with a value of 1 if the farmer's backyard pig production system was sustainable and 0 if not sustainable. The predictor variables of the study were age, educational attainment, number of dependent household members, available family labor, monthly household income, gender, organizational affiliation, access to bank credit, access to sources of credit other than bank, being contract or independent grower, extension exposure, access to market, and tolerance by neighbors. Table 1 contains the list of variables, variable types and measurement methods.

Table 1:- Description of the variables used in the logit model

\begin{tabular}{|c|c|c|}
\hline Explanatory variable & $\begin{array}{l}\text { Variable } \\
\text { Type }\end{array}$ & Measurement \\
\hline Sustainability & Dummy & $\begin{array}{l}1 \text { if the backyard pig farming system is sustainable which means the } \\
\text { farmer continued backyard swine raising for at least six cycles in } 3 \\
\text { years, otherwise } 0\end{array}$ \\
\hline Age & Continuous & Age of the backyard pig farmer (years) \\
\hline Educational attainment & Continuous & Formal education of the backyard pig farmer (years of schooling) \\
\hline $\begin{array}{l}\text { Number of dependent } \\
\text { members }\end{array}$ & Continuous & $\begin{array}{l}\text { Number of dependent members (aged }<16 \text { or }>65 \text { years) in the family } \\
\text { (persons) }\end{array}$ \\
\hline Family labor size & Continuous & $\begin{array}{l}\text { Number of family members that can work in the backyard pig farm } \\
\text { (persons) }\end{array}$ \\
\hline Household income & Continuous & Amount of money earned by the family members in a month (Php) \\
\hline Gender & Dummy & 1 if the backyard pig farmer is male, otherwise 0 \\
\hline Organizational affiliation & Dummy & $\begin{array}{l}1 \text { if the backyard pig farmer is a member of any } \\
\text { organization/association of swine raisers }\end{array}$ \\
\hline $\begin{array}{l}\text { Farmer's access to bank } \\
\text { credit }\end{array}$ & Dummy & $\begin{array}{l}1 \text { if the farmer or at least } 1 \text { family member has access to bank credit, } \\
\text { otherwise } 0\end{array}$ \\
\hline $\begin{array}{l}\text { Access to other credit } \\
\text { facilities }\end{array}$ & & $\begin{array}{l}1 \text { if the farmer or at least } 1 \text { family member has access to credit other } \\
\text { than bank credit, otherwise } 0\end{array}$ \\
\hline $\begin{array}{l}\text { Contract or independent } \\
\text { grower }\end{array}$ & Dummy & 1 if the backyard pig farmer is in contract growing, otherwise 0 \\
\hline Extension exposure & Dummy & 1 if the backyard pig farmer is exposed to extension, otherwise 0 \\
\hline Access to market & Dummy & $\begin{array}{l}1 \text { if household has access to market for disposing finished hogs on time } \\
\text { and acceptable payment schemes, otherwise } 0\end{array}$ \\
\hline
\end{tabular}




\begin{tabular}{|l|l|l|}
\hline Tolerance by neighbors & Dummy & $\begin{array}{l}1 \text { if the neighbors have no complaint of foul odor, noise, and other } \\
\text { nuisance from backyard farms and } 0 \text { otherwise }\end{array}$ \\
\hline
\end{tabular}

\section{Results and Discussion:-}

Table 2 presents the mean, standard error and results of t-tests comparing the two groups of respondents. Results revealed significant differences between the sustainable and not-sustainable groups of respondents in terms of their household income, organizational affiliation, access to credit sources other than banks, being contract or independent grower, extension exposure and tolerance by neighbors. The differences were all positive which means that the measures for the group with sustainable backyard farming were significantly higher than those for group whose backyard pig production systems were not sustainable. On the other hand, differences between the two groups in terms of age, educational attainment, number of dependent members, family labor size, access to bank credit, and access to market were not significant.

Table 2:- Comparison of the mean values for sustainable and not-sustainable backyard pig farming groups based on explanatory variables

\begin{tabular}{|l|l|l|l|l|l|}
\hline \multirow{2}{*}{ Explanatory variable } & \multicolumn{2}{|l|}{ Mean and Standard Error } & Difference & T-value & P-value \\
\cline { 2 - 5 } & $\begin{array}{l}\text { Sustainable } \\
\mathrm{n}=26\end{array}$ & $\begin{array}{l}\text { Not Sustainable } \\
\mathrm{n}=34\end{array}$ & & & \\
\hline Age of respondent & $46.2 \pm 2.4$ & $41.9 \pm 1.7$ & 4.25 & 1.46 & $0.149^{\mathrm{ns}}$ \\
\hline Educational attainment of respondent & $10.15 \pm 0.54$ & $9.94 \pm 0.43$ & 0.213 & 0.31 & $0.757^{\mathrm{ns}}$ \\
\hline Number of dependents in the family & $1.62 \pm 0.22$ & $1.56 \pm 0.19$ & 0.057 & 0.19 & $0.847^{\mathrm{ns}}$ \\
\hline Available family labor & $4.69 \pm 0.40$ & $4.68 \pm 0.28$ & 0.016 & 0.03 & $0.973^{\mathrm{ns}}$ \\
\hline Family income & $15385 \pm 1683$ & $8824 \pm 960$ & 6560 & 3.58 & $0.001^{* *}$ \\
\hline Gender & $0.346 \pm 0.095$ & $0.382 \pm 0.085$ & -0.036 & -0.28 & $0.778^{\mathrm{ns}}$ \\
\hline Organizational affiliation & $0.731 \pm 0.089$ & $0.294 \pm 0.079$ & 0.437 & 3.66 & $0.001^{* *}$ \\
\hline Access to bank credit & $0.269 \pm 0.089$ & $0.206 \pm 0.070$ & 0.063 & 0.57 & $0.573^{\mathrm{ns}}$ \\
\hline Access to credit sources other than bank & $0.731 \pm 0.089$ & $0.206 \pm 0.070$ & 0.525 & 4.70 & $0.000^{* *}$ \\
\hline Contract or independent farmer & $0.654 \pm 0.095$ & $0.265 \pm 0.077$ & 0.389 & 3.22 & $0.002^{* *}$ \\
\hline Extension exposure & $0.692 \pm 0.092$ & $0.294 \pm 0.079$ & 0.398 & 3.28 & $0.002^{* *}$ \\
\hline Market of the product & $0.538 \pm 0.10$ & $0.353 \pm 0.083$ & 0.186 & 1.44 & $0.156^{\mathrm{ns}}$ \\
\hline Tolerance/Complaint from neighbors & $0.615 \pm 0.097$ & $0.324 \pm 0.081$ & 0.292 & 2.31 & $0.024^{*}$ \\
\hline $\begin{array}{l}* \\
\text { significant at } \alpha=0.05(\mathrm{P}>0.01, \mathrm{P} \leq 0.05) \\
* *\end{array}$ \\
ns significant at $\alpha=0.01(\mathrm{P} \leq 0.01)$
\end{tabular}

Age:-

Results of logistic regression show that respondent's age is not a factor of continuity of backyard pig production. Substantiating this result is the finding of Rahman (2007) that among the pig farmers of Aizawl district of Mizoram, India, age did not influence the adoption of pig farming technologies. Further, Petrus et al. (2011) explained that pig farming in the rural areas of Etayi Constituency of Namibia is participated by the adult and young members of the family. This result is in contradiction with the findings of Asiabaka and Owens (2002) that age is one of the farmers' socioeconomic characteristics that influenced the adoption behavior of rural farmers in Nigeria. Age was shown to be negatively correlated with technology adoption among pig farmers in Ashanti region of Ghana (Zanu, 2012) and among the smallholder pigs production in Tanzania (Kimbi et al. 2015).

\section{Educational attainment:-}

Education is often expected to have a positive influence on farmers' decision to adopt new technology. This is because education level of a farmer increases his ability to access, understand and utilize information relevant to his decision to adopt technology (Mignouna, 2011). Asiabaka and Owens (2002) found that in rural Nigeria, education is one of the socioeconomic characteristics that influenced the farmers' adoption behavior. However, in this study, educational attainment was found to have no significant influence on the decision of backyard pig farmers on whether to continue or not their backyard pig operation. Similar result was shown by the study of Rahman (2007) that along with 14 other independent variables, education level had no significant contribution to the adoption of improved technologies by the pig farmers of Aizawl district of Mizoram, India. Likewise, in Ashanti region of Ghana, education is not a factor of technology adoption among pig farmers (Zanu et al., 2012). 


\section{Number of dependent household members:-}

Family size exerts pressure on the farmers' production decision (Zanu et al., 2012). The number of dependent family members puts more pressure to the farming household head. For the purpose of earning additional income, he/she may wish to continue the backyard pig farming but the same pressure may compel him/her to stop the venture. In case of limited income, the farmer has to prioritize supporting the need of humans over that of the animals. Conversely, the number of dependent members was found in the present study to be not a significant factor that influenced the pig farmers' decision to continue or stop backyard pig operation.

\section{Family labor size:-}

The number of family members that can provide labor was found to be not a significant factor of sustainability of backyard pig farming. This is because labor is generally not a scarce resource in small farm operation. In a study conducted at Etayi Constituency of Namibia, Petrus et. al. (2011) revealed that unpaid family labor is usually available and that the whole family is involved in the rearing of pigs in the rural areas. The adult and young members, especially women and girls, participate in feeding. It was also reported that $57 \%$ and $39 \%$ of the caretakers of pigs were wives and young girls. The adoption of pig farming technology by the pig farmers of Aizawl district of Mizoram, India was also not influenced by family size (Rahman, 2007).

\section{Household income:-}

Household income significantly affects the decision of farmers to sustain backyard pig farming. The lack of income to support the backyard pig production sometimes forced the respondents to stop their operation. This can be compared to adoption of technologies that require large amount of investment. Lapar et al. (2006) explained that many smallholder pig producers in Vietnam practice conventional and low-level production technologies because they are constrained by limited financial resources. It was suggested that to reduce the financial constraints of animal producers, they should have better credit access

Household income is shown to be positively related to sustainability of backyard pig farming. Those with higher income were more able to sustain their farming operation. The income in excess of the amount required by the household for its members' needs can be used to support the expenses in the farm especially on feed. Such income can be used as substitute for borrowed capital in rural economies especially for households with credit constraints (Diiro, 2013). Pig farming is a capital-intensive practice and smaller-sized producers encounter financial constraints when it comes to access to feeds and quality breeding stocks, and access to veterinary services (Costales et al. 2006). Income earned particularly from off- farm sources can be a source of liquid capital for purchasing productivity enhancing inputs (Diiro, 2013; Mwangi and Kariuki, 2015). Another form of financial difficulty is when emergency needs occur; the farmers sell the pigs even if these animals have not yet reached market weight. Petrus et. al. (2011) reported that smallholder farmers in Etayi Constituency of Namibia, slaughtered their pigs when unexpected needs occurred or when particular farmers had nothing to feed their pigs. Such situations forced farmers to stop their backyard pig farming operation. Therefore, the farmers with higher household incomes have greater chance of continuing the backyard pig farming, The importance of household income is also emphasized by the report of Aquino and Malazo (n.d) that in 2004, the output of the Philippine swine industry declined minimally after several years of continued growth which was partly due to the closure of some backyard pig operations. The low-income backyard operators were constrained by great increases in cost of feeds and drugs.

\section{Gender:-}

Pig farming in the rural areas of Etayi Constituency of Namibia is participated by the adult and young females especially in feeding. It was also reported that $57 \%$ and $39 \%$ of the caretakers of pigs were wives and young girls (Petrus et al., 2011). Zanu et al.(2012)discovered that in Ashanti region of Ghana the high percentage of men involved in pig production than women was because the venture is both labor- and capital-intensive. The great physical exertion and labor input required by pig farming discourage women participation. A significant correlation +0.26 between sex and adoption was obtained. The inconsistent findings on the relationship between gender and adoption decision imply that more studies on this topic are needed and that the role of women in livestock development such as in rearing, on-farm processing and marketing of livestock products must be highlighted (Kaasschieter, 1992).

\section{Organizational affiliation:-}

Organizational affiliation significantly contributed to the farmers' decision to continue backyard pig production. With membership in organizations, farmers may have better access to veterinary services, production and marketing 
information, and supply of feed and feed ingredients. In a related study, it was suggested that local organizations could be considered an alternative to the traditional agricultural extension model for dissemination of agricultural technologies in many sub-Saharan countries (Katungi and Akankwasa, 2010). This is because local organizations are generally perceived as a more efficient channel for disseminating technologies to many farmers (Godquin and Quisumbing, 2006) aside from being a source of social capital that facilitates resources and information sharing among actors (Ojiako, 2013). In a social group or network, the members gain confidence, trust and belongingness and it where they usually have exchange or sharing of ideas and information; they learn from one another. The effect of organizational affiliation is important for individual decisions. Awotide (2013) indicated that formation of associations among the rural farmers should be encouraged. It is then believed that it will be possible for agricultural development agencies to achieve great success when they work in collaboration with farmers' organizations (Verteeg and Koudokpon, 1993).

Many farmers in Asian developing countries are small farmers with less than one hectare of cultivated land. One of the main difficulties for small farmers is how to gain power in a value chain that the more powerful actors such as traders, agro-enterprises and exporters usually have. One way to overcome such difficulty and to have a mechanism to improve access to information, capital and relevant contacts is through joining farmer organizations including farmer groups, cooperatives and farmer association (Lapar et al., 2006).

Based on the results of their analysis of the production and marketing operations of swine enterprises in the Philippines Aspile et al. (2015) recommended the clustering municipal hog raisers and traders into cooperative, increasing production volume, adopting a community-based approach in herd-health improvement, encouraging joint production of commercial and backyard swine farms, and increasing efforts to promote social awareness regarding environmental impact of swine production.

A study on the adoption of improved technologies by the pig farmers of Aizawl district of Mizoram, India showed a positive and significant relationship between social participation with adoption level of farmers. Social participation helped the farmers in gaining more information on improved technologies in their farms (Rahman, 2007). In the review of pig production in Cambodia, Laos, Philippines, and Vietnam by Huynh et al. (2006), it was concluded that the sustainable development of pig production might require a new form of intensive and complex farming systems on the existing small-scale farms such as pig farming associations, and crop-animal integrated farms.

\section{Access to credit:-}

The lack of income to support the backyard pig production sometimes forced the respondents to stop their operation. This can be compared to adoption of technologies that require large amount of investment. Lapar et al. (2006) explained that many smallholder pig producers in Vietnam practice conventional and low-level production technologies because they are constrained by limited financial resources. It was suggested that to reduce the financial constraints of animal producers, they should have better credit access. Mwangi and Kariuki (2015) explained that credit is an important instrument for improving the welfare of the poor directly through consumption smoothening that reduces their vulnerability to short-term income. It is believed that access to credit promotes the adoption of risky technologies through relaxation of the liquidity constraint as well as through the boosting of household's-risk bearing ability. This is because with an option of borrowing, a household can do away with risk reducing but inefficient income diversification strategies and concentrate on more risky but efficient investments (Simtowe and Zeller, 2006). Farmers of Etayi Constituency of Namibia were not able to expand their herd sizes due to lack of access to micro-finance or credit to (Petrus et. al., 2011).

Two types of credit source were discussed in this study- banks and other sources like microfinance and informal sources such as friends, relatives and feed and veterinary supply stores. Based on the results, farmer's access to bank credit did not influence significantly the decision of the respondents to sustain backyard pig farming operation while access to credit facilities other than banks had significant influence. Nimoh et al. (2013) found out that most farmers in Ga East Municipality, Ghana preferred to borrow from informal financial institutions; the reasons mentioned among others were the arduous procedures, not releasing funds when already needed, and high interest rates from formal lenders like banks. They rather would prefer borrowing from other private commercial lenders. Their study however revealed that most farmers had multiple accounts and mostly supplemented formal institutional funding with credit from either friends or relatives or other convenient sources. In the Philippines, one of the recommendations to improve the swine industry was for the government to provide the small pig producers low interest loans (Aspile et al., 2015) 


\section{Being Contract or independent grower:-}

This study revealed that being a contract grower is a favorable factor to the continuity of backyard pig farming. In the area of the present study, contract growing is practiced by most of the small backyard pig raisers who were able to have sustainable production. The contractor is a feed milling firm that also operates several commercial swine farms. The weanlings, veterinary and other technical services, feed, veterinary supplies and market of finished hogs are the responsibility of the contractor while the housing, labor and herd management are shouldered by the farmer grower.

Phil Psilos (2007) reported that the contract farming system is in widespread use in Thailand, and growing in popularity in Vietnam. The system represents an asymmetric but mutually beneficial compromise between pig raisers and industrial producers/processors. Contract farming, a strategy of integrator firms, may offer both challenges and opportunities for smallholders, exerting significant influence on the value chain in all countries where it is being practiced.

Growers in the US have embraced contracting as a means of reducing risk, accessing capital, and stabilizing income. It was also cited that survey results suggest that risk reduction is the leading reason that producers enter into contract arrangements, followed by a lack of capital and the need for more income (McBride and Nigel Key, 2003). Several studies have demonstrated that risk-averse producers prefer contracting to independent production (Martin, 1997).

\section{Extension exposure:-}

Agricultural extension is one of the policy instruments which is used to support agricultural development, and extension workers play a vital role in educating farmers to produce better crops and more productive animals at lower cost. Farmers of Etayi Constituency of Namibia also indicated that they struggled to get extension services and customers. They also had no access to micro-finance or credit to enable them to expand their herd sizes (Petrus et. al., 2011).

Generally, smallholder farmers in the developing world have limited expertise resulting in poor management and planning of pig enterprises. This lack of technical know-how is a common problem and is coupled with a general lack of supporting services (Steinfeld and Mac 1997). This could be rectified mainly by an improvement in extension services, making available credit facilities and by improving communication networks (roads and telephones) (Petrus et. al., 2011).

Chantalakhana (1990) identified farmer training, increased interest in new technologies as two of the determinants of sustainable small farm animal production in less developed countries. It was explained that increasing productivity need strong support for research and development. Improved productivity can, in turn, help make small farm animal production in LDCs sustainable. Bringing the technology to farmers and convincing them to adopt is the role of extension agents

The significant influence of extension variables such as visits by extension agents or consultation with them, credibility of the extension agents, availability of reading materials and continuity of receiving information about the technology is explained by Godquin and Quisumbing (2006). According to them farmers can obtain knowledge and information from extension agents, demonstration farms, farm tours and/or contact with other farmers, as well as from mass media and published materials. The education that farmers get enhances their ability to acquire and synthesize the information and consequently help them in making decisions (Perey, 2016).

\section{Access to market:-}

Access to market both for procuring inputs and disposing finished hogs is important. Thus, alleviating constraints to marketing, improving marketing and market information, and upgrading marketing infrastructures will potentially increase the welfare of smallholder producers and urban consumers in Ethiopia (Ayele et al., 2003). For the poor smallholders in Uganda, pigs are important as they generate income for financing planned and emergency household needs. One of the constraints of the smallholder pig systems were poorly organized markets (Ouma, 2013). The cited literatures negate the findings of the present study which showed that access to market has no significant contribution to the sustainability of backyard pig production. This is because acquisition of inputs especially feed and veterinary supplies are always available in the local market and there is high demand for both finished hogs and pork. Furthermore, the respondents who were in contract growing did not have problems on marketing their finished hogs because the contractor took the responsibility of marketing the animals. 


\section{Complaint by neighbors:-}

In the Philippines, the usual practice of backyard pig raisers is sweeping the liquid and solid wastes to canals that will eventually drain to rivers. Some contain the waste in open lagoons (Acantara and Donald, 1996). At the time of the present study, no formal complaints regarding the nuisance from their backyard pig farming operation were reported by the respondents. Thus complaints by neighbors is not a significant factor of the sustainability of the backyard pig farming operation. The major constraints to pig production in the Mecha District, Amhara Region, Northwestern Ethiopia were reported according to their order of importance by Mekuriaw and Asmare (2014) as feed availability and cost, shortage of water, cost of medicine, and lack of skilled veterinarians on pig diseases and poor preventive health care. same constraints were reported by Tekle et al. (2013) among the smallholder pig producers Mekelle and southern zone of Tigray Region, North Ethiopia. Nothing was mentioned about the complaints by neighbors. However, complaints are usually encountered by commercial piggery operators. As swine manure emits methane, nitrous oxide, and other gases, the usual complaints of residents concerning piggeries is the emission of foul odors (Catelo et al.1996; Nowlin, 2013). The storage and disposal of large volumes of minimally treated manure in concentrated animal feeding operations (CAFOs) in North Carolina created tremendous problems for neighbors who complained about the foul odor and health risks (Nowlin, 2013).

Table 3:- Results of logistic regression analysis

\begin{tabular}{|l|l|l|l|l|l|}
\hline Source & DF & Adj Dev & Adj Mean & Chi-Square & P-Value \\
\hline Regression & 13 & 52.0539 & 4.0041 & 52.05 & $0.000^{* *}$ \\
\hline Age of respondent & 1 & 0.3695 & 0.3695 & 0.37 & $0.543^{\text {ns }}$ \\
\hline Educational attainment of respondent & 1 & 1.3399 & 1.3399 & 1.34 & $0.247^{\text {ns }}$ \\
\hline Number of dependents in the family & 1 & 0.5362 & 0.5362 & 0.54 & $0.464^{\text {ns }}$ \\
\hline Available family labor & 1 & 0.1805 & 0.1805 & 0.18 & $0.671^{\text {ns }}$ \\
\hline Family income & 1 & 6.7459 & 6.7459 & 6.75 & $0.009^{* *}$ \\
\hline Gender & 1 & 2.5130 & 2.5130 & 2.51 & $0.113^{\text {ns }}$ \\
\hline Organizational affiliation & 1 & 4.4624 & 4.4624 & 4.46 & $0.035^{*}$ \\
\hline Access to bank credit & 1 & 2.0492 & 2.0492 & 2.05 & $0.152^{\text {ns }}$ \\
\hline Access to credit sources other than bank & 1 & 8.2635 & 8.2635 & 8.26 & $0.004^{* *}$ \\
\hline Contract or independent farmer & 1 & 4.7874 & 4.7874 & 4.79 & $0.029^{*}$ \\
\hline Extension exposure & 1 & 6.1559 & 6.1559 & 6.16 & $0.013^{*}$ \\
\hline Market of the product & 1 & 2.3886 & 2.3886 & 2.39 & $0.122^{\text {ns }}$ \\
\hline Tolerance/Complaint from neighbors & 1 & 0.9097 & 0.9097 & 0.91 & $0.340^{\text {ns }}$ \\
\hline Error & 46 & 30.0539 & 0.6533 & & \\
\hline Total & 59 & 82.1078 & & & \\
\hline
\end{tabular}

* significant at $\alpha=0.05(\mathrm{P}>0.01, \mathrm{P} \leq 0.05)$

** significant at $\alpha=0.01(\mathrm{P} \leq 0.01)$

${ }^{\mathrm{ns}}$ not significant $(\mathrm{P}>0.05)$

Model Summary

Deviance: $\mathrm{R}-\mathrm{Sq}=63.40 \% \quad \mathrm{R}-\mathrm{Sq}(\mathrm{adj})=47.56 \% \quad \mathrm{AIC}=58.05$

\section{Conclusion:-}

The factors that contribute significantly to the smallholder pig producers' decision to continuously engage in backyard pig farming are family income, organizational affiliation, access to credit sources other than bank, being contract or independent farmer, and extension exposure. On the other hand, age of respondent, educational attainment of respondent, number of dependents in the family, available family labor, gender, access to bank credit, market of the product, and tolerance/complaint from neighbors. The findings underscored the importance of financial resources (such as family income, credit that is easy to access, and contract growing scheme) for supporting backyard pig production, and enhanced social capital (organizational affiliation and extension exposure) for the farmers to continue in engaging in the venture. Prospective businessmen, extensionists and policy makers can consider these factors in planning and designing a sustainable pig production for smallholder farmers. 


\section{References:-}

1. Aquino, J.T., Jr., and Malazo, M.S. (n.d): Cost reduction technology on backyard swine production. A phamplet. Livestock FITS Center Department of Agriculture, Sta. Barbara,Pangasinan

2. Asiabaka, C.C. and Owens, M. (2002): Determinants of adoptive behaviors of rural farmers in Nigeria AIAEE 2002 Proceedings of the 18th Annual Conference Durban, South Africa

3. Aspile, S.C.K.C., Manipol, N.E.P., Depositario, D.P.T. and Aquino, N.A. (2015): Analysis of the production and marketing operations of swine enterprises in the City of San Jose del Monte and Santa Maria, Bulacan, Philippines. University of the Philippines Mindanao

4. Awotide, B.A., Diagne, A. and Awoyemi, T.T. (2013): Agricultural technology adoption, market participation and rural farming households' welfare in Nigeria. Contributed paper prepared for presentation at the $4^{\text {th }}$ International Conference of the African Association of Agricultural Economists, Hammamet, Tunisia. September 22-25,

5. Ayele S., Assegid, W., Jabbar, M.A., Ahmed M.M. and Belachew, H. (2003): Livestock marketing in Ethiopia: A review of structure, performance and development initiatives. Socio-economics and Policy. Addis Ababa, Ethiopia.

6. Chantalakhana, C. 1990: Small farm animal production and sustainable agriculture. In: Extension Bulletin No. 309 September 1990. Food and Fertilizer Technology Center. Taipei City, Republic of China on Taiwan

7. Costales, A., Delgado, C., Catelo, M.A., Lapar, M.L., Tiongco, M., Ehui, S. and Bautista A.Z. (2006):Scale and access issues affecting smallholder hog producers in an expanding peri-urban market: Southern Luzon, Philippines. pp. 171.

8. Diiro, G. (2013): Impact of off-farm income on technology adoption intensity and productivity: Evidence from rural maize farmers in Uganda. International Food Policy Research Institute, Working Paper11

9. Godquin, M. and Quisumbing, A. R. (2006): Groups, Networks and social capital in rural Philippine communities. CAPRi Working Paper \#55. IFPRI, Washington DC

10. Huynh, T.T.T.A, Aarnink, J. A., Drucker A. and. Verstegen, M.W.A. (2006): Pig Production in Cambodia, Laos, Philippines, and Vietnam: A Review. Asian Journal of Agriculture and Development, Vol. 3, No. 1 \& 2 2006

11. Kaasschieter, G.A., de Jong,R., Schiere, J.B. and Zwart, D. (1992): Towards a sustainable livestock production in developing countries and the importance of animal health strategy therein, Veterinary Quarterly, 14:2, 66-75, DOI: 10.1080/01652176.1992.9694333

12. Katungi E. and Akankwasa, K.(2010): Community-based organizations and their effect on the adoption of agricultural technologies in Uganda: a study of banana (Musa spp.). pest management technology. National Banana Research Program, Acta Hort., 879, ISHS.

13. Kimbi, E., Lekule, F., Mlangwa, J., Mejer, H. and Thamsborg, S. (2015): Smallholder Pigs Production Systems in Tanzania. Journal of Agricultural Science and Technology A 5 (2015) 47-60. doi: 10.17265/21616256/2015.01.007

14. Lapar, M.L.A., Binh,V.T., Son, N.T., Tiongco, M., Jabbar, M., and Staal, S. (2006): The role of collective action in overcoming barriers to market access by smallholder producers: some empirical evidence from Northern Vietnam. Paper Presented at the Workshop on "Collective Action and Market Access for Smallholders". October 2-5, 2006. Cali: Colombia.

15. Martin, L.L. (1997): Production contracts, risk shifting, and relative performance payments in the pork industry. Journal of Agricultural and Applied Economics. (29):267-278.

16. McBride W.D. and Key, N. (2003): Economic and structural relationships in U.S. hog production. Resource Economics Division, Economic Research Service, U.S. Department of Agriculture. Agricultural Economic Report No. 818. 1800 M Street, NW Washington, DC 20036-5831 February 2003

17. Mignouna, B., Manyong, M., Rusike, J., Mutabazi, S., andSenkondo, M. (2011): Determinants of adopting Imazapyr-resistant maize technology and its impact on household income in Western Kenya: AgBioforum, $14(3), 158-163$.

18. Minitab Inc. (2013): Binary logistic regression, in Minitab Free 30-day Trial. Minitab Inc., USA

19. Mwangi, M. and Kariuki, S. (2015): Factors determining adoption of new agricultural technology by smallholder farmers in developing countries. Journal of Economics and Sustainable Development Vol.6, No.5, 2015 www.iiste.org

20. Nimoh, F., Tham-Agyekum, E.K. and Awuku, M.S. (2013): Factors influencing access of poultry farmers to credit: the case of the Agricultural Development Bank (ADB) in Ga East Municipality, Ghana. Management 2013, 3 (1): 54-58 DOI: 10.5923/j.mm.20130301.11 
21. Ojiako, I. A., Manyong,V.M. and Ikpi, A.E.(2007): Determinants of rural framers' improved soybean adoption decision in Northern Nigeria, Journal of Food, Agriculture and Environment, Vol. 5(2): 215-223

22. Ouma, E.,Dione, M., Lule, P., Rosel, K. and Pezo, D. (2013):Characterization of smallholder pig production systems in Uganda: constraints and opportunities for engaging with market systems. Invited paper presented at the 4th International Conference of the African Association of Agricultural Economists, September 22-25, 2013, Hammamet, Tunisia

23. Perey, E.R. (2016): Motivational factors on the adoption of natural farming technology. Res. J. Agriculture \& Forestry Sci., Volume 4, Issue (1), Pages 14-19

24. Petrus N.P., Mpofu, I., Schneider,M.B. and Nepembe, M.(2011): The constraints and potentials of pig production among communal farmers in Etayi Constituency of Namibia. Livestock Research for Rural Development. Volume 23, Article \#159.

25. Philippine Statistics Authority. (2016):Swine industry report September 2016. Philippine Statistics Authority, Quezon city, Philippines

26. Phil Psilos. (2007): Smallholder swine-pig meat production in Asia, a conceptual framework for competitiveness: using analysis from the lower Mekong Region, Swine/Pig Meat Competitiveness Framework Concept Note, PSA RAP-159-10-2007

27. PigProgress.(2016): Changing the mindset of Philippine pig farmers. In: Vincent ter Beek, ed. published online Dec. 11, 2015

28. Querol. M.A.P. (2011):Learning challenges in biogas production for sustainability: an activity theoretical study of a network from a swine industry chain. Dissertation, University of Helsinki Institute of Behavioural Sciences Studies in Educational Sciences

29. Rahman S. (2007): Adoption of improved technologies by the pig farmers of Aizawl district of Mizoram, India Livestock Research for Rural Development 19 (1)

30. Simtowe, F. andZeller, M.(2006):The impact of access to credit on the adoption of hybrid maize in Malawi: An empirical test of an agricultural household model under credit market failure. MPRA Paper No.45

31. Stanton, Emms and Sia. 2010. The Philippines pig farming sector: a briefing for canadian livestock genetics suppliers. Agriculture and Agri-Food Canada.

32. Tekle, T., Tesfay, A. and Kifleyohannes, T. (2013):Smallholder pig production and its constraints in Mekelle and southern zone of Tigray region, north Ethiopia. Livestock Research for Rural Development 25 (10)

33. Verteeg, M.N. and Koudokpon, V.(1993):Participatory farmer testing of four low external input technologies to address soil fertility decline in mono province (Benin), Agricultural systems 42: 265-276

34. Zanu, H.K., Antwiwaaand,A. and Agyemang C.T.(2012):Factors influencing technology adoption among pig farmers in Ashanti region of Ghana. Journal of Agricultural Technology Vol. 8(1): 81-92. 